\title{
FRUIT FLIES (DIPTERA: TEPHRITIDAE) DIVERSITY IN HORTICULTURAL FARM OF MERAWANG SUB-DISTRICT, BANGKA DISTRICT, BANGKA BELITUNG ISLANDS
}

\author{
Rahayu Supratiwi, Rion Apriyadi, \& Euis Asriani \\ ${ }^{1}$ Agrotechnology Study Program, Faculty of Agriculture, Fisheries, and Biology, Bangka Belitung University, Indonesia \\ Jl. Kampus Terpadu UBB, Merawang, Kepulauan Bangka Belitung, 33172 \\ E-mail : rahayusupratiwi16@gmail.com
}

Manuscript received: 2 March 2019. Revision accepted: 8 March 2020

\begin{abstract}
Fruit flies (Diptera: Tephritidae) diversity in horticultural farm of Merawang Sub-District, Bangka District, Bangka Belitung Islands. Fruit flies (Diptera: Tephritidae) are main pests in fruit and vegetable cultivation. There are 4000 species of fruit flies in the world and $35 \%$ of them are important pests, including commercial fruits that have high economic value. Merawang District is one of the centers of horticultural production, especially fruits and vegetables. One of the threats to the production of horticultural commodities is the attack of fruit flies. The purpose of this study was to determine the diversity, distribution, and types of fruit flies in horticultural crops in Merawang Sub-District, Bangka District. The research was conducted in descriptive method, in this case, the survey method was also used. The sampling was done in purposive sampling method. In total, 1248 specimen of fruit flies were collected by using different attractant traps and identified. The methyl eugenol (ME) and cue lure (CUE) attractants trapped 1076 and 172 specimens, respectively. The diversity of fruit flies in Merawang Sub-District was relatively low, in total 9 species fruit flies were observed and identified as Bactrocera dorsalis (Hendel), B. umbrosa (Fabricius), B. carambolae (Drew \& Hancock), B. occipitalis (Bezzi), Zeugodacus cucurbitae (Coquillett), B. albistrigata (de Meijer), Z. caudata (Fabricius), B. limbifera (Bezzi), and Dacus nanggalae (Drew \& Hancock). The species dominant observed at the study site were B. dorsalis (Hendel), B. carambolae (Drew \& Hancock), and B. occipitalis (Bezzi). Air Anyir Village was the highest number of fruit flies species.
\end{abstract}

Key words: cue lure, diversity, fruit flies, metyl eugenol

\section{INTRODUCTION}

Fruit flies (Diptera: Tephritidae) are the main pests in fruits and vegetables crops (Larasati et al., 2016). Fruit flies attack on fruits with soft and thin skin (Ginting, 2009). There are 4000 species of fruit flies in the world and $35 \%$ of them are important pests, including commercial fruits that have high economic value (Nawawi, 2018). About $40 \%$ of fruit fly larvae were also live and thrive in the Asteraceae family (Astriyani et al., 2016). About $75 \%$ of fruit crops cultivated in Indonesia have been attacked by fruit flies (Sarjan $e t$ al., 2010).

The early symptoms of fruit fly attacks were characterized black spots on the surface of fruit skin due to the pricking of the female imago ovipositor found in nearly ripe fruit (Khaeiruddin, 2015). Fruit flies belong to the Dacini Tribe which consists of 4 genera, viz. Monacrostichus, Bactrocera, Zeugodacus, and Dacus which is spread almost throughout the Asia Pacific
(Doorenweerd et al., 2018). Bactrocera is a genus of tropical origin which is economically an important fruit fly associated with various tropical fruits. One of its species that causes severe damage to horticultural crops in Asia (especially Southeast Asia), namely Bactrocera dorsalis (Hendel). This species is also an important pest in western Indonesia (Astriyani, 2014).

Research on fruit flies in South Sumatera by Pujiastuti (2009), identified the species of fruit flies as B. albistrigata, B. carambolae, and B. papayae. Isnaini (2013) reported in Demak District found that $B$. papayae attacked mango, $B$. carambolae attacked guava, $B$. albistrigata attacked water apple, and B. mcgregori attacked melinjo.

Species diversity is very important in determining the extent of damage to natural systems due to human intervention (Micheal, 1994). The study of the diversity of fruit flies is expected to be useful as additional information about the presence of fruit flies, as a basis for pest control. Information about the type of fruit flies 
on horticultural crops in Merawang Sub-District, Bangka District has never been done, therefore it is necessary to survey and identify fruit flies to determine the diversity of fruit flies in Merawang Sub-District, Bangka District, Bangka Belitung Islands.

\section{MATERIALS AND METHODS}

Research Site. This research was conducted in November 2018-January 2019 in Merawang SubDistrict, Bangka District, Bangka Belitung Islands. Fruit fly specimens were identified at the Agrotechnology Laboratory, Faculty of Agriculture, Fisheries and Biology, Bangka Belitung University. The sampling location and technique was conducted by using purposive sampling method. The sampling site was determined by considering the data from the Central Bureau of Statistics of Bangka District (BPS, 2017) concerning the total area of horticultural crops which was the largest area of horiculture farms in Merawang Sub-District. The following 6 villages were selected as research locations, namely Balunijuk, Jada Bahrin, Pagarawan, Air Anyir, Kimak, and Batu Rusa. The location of the study is shown in Figure 1. In each village, two farmers were selected based on several criteria, such as farmers who cultivate horticultural crops in the field and the distance between horticultural farmer's fields and others $>100 \mathrm{~m}$. Data was collected on the area of farmer's land that meets the criteria. If there were more than two farmers in the village, selection of farmers in each village was determined by accidental sampling technique.
Trap Making. Traps were made from $1500 \mathrm{~mL}$ mineral water bottles. One-third of the head of the bottle was cut, then inserted into the bottle with the mouth of the bottle inside (bottle cap opened). The front and back of the bottle were tied with string for easy hanging (Figure 2).

Trap Installation. Fruit fly traps were installed once at each point of the study site, two traps each for methyl euganol (ME) and cue lure (CUE). Fruit fly traps were installed in horticultural crops such as vegetable fruit plants. The inserted cotton ball was dropped by attractants in a ratio of $3: 1$ (Larasati et al., 2013). Sampling was done once for each site and the interval was two days after trap installation at the research location.

Preference and Identification. The trapped imago were collected and stretched using pointing techniques before the drying process. The collected fruit flies were identified based on the morphological characteristics of the head, thorax, wings, and abdomen by using the dichotomous determination reference by Larasati et al. (2016), Khaeruddin (2015), and Plant Health Australia (2018). The data obtained was presented as images and descriptions.

Data Analysis. The diversity of fruit flies was analyzed descriptively, qualitatively, and quantitatively. Qualitative data was presented as images. Quantitative descriptive analysis was used to observe the number, type, and diversity of fruit flies in each type of attractant. The

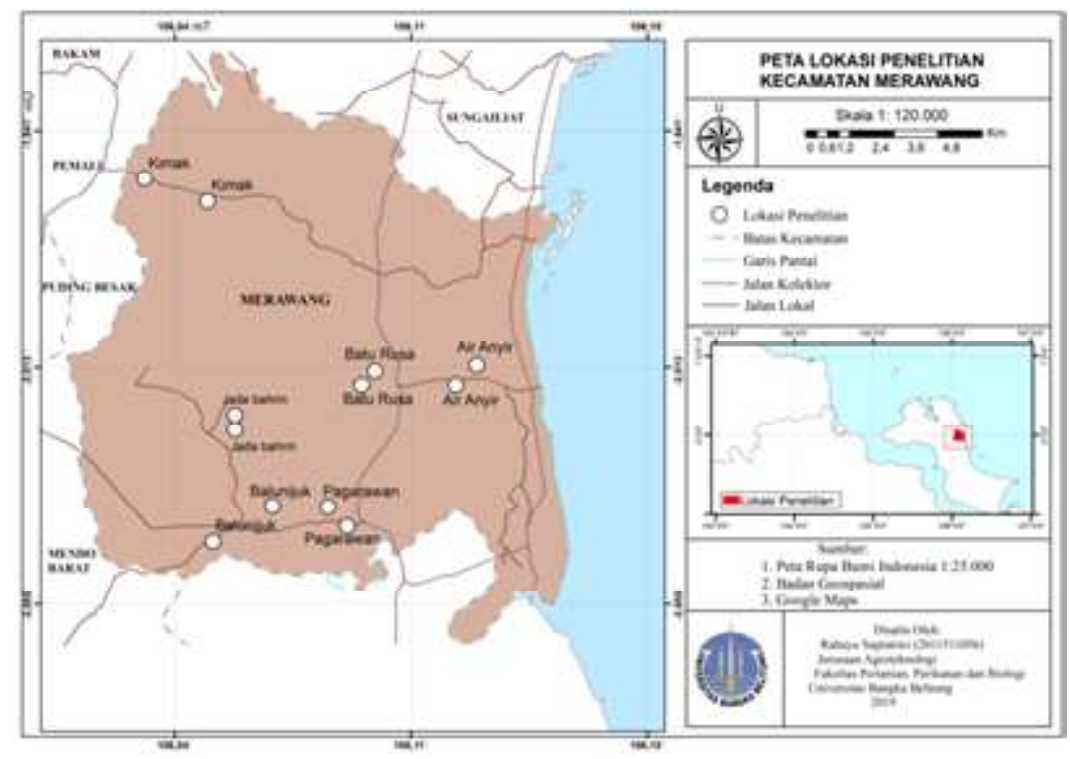

Figure 1. Map of research locations in Merawang Sub-District, Bangka District, Bangka Belitung Islands Province. 
number of fruit flies in each research location, dominance category, categorization of dominance fly species were done by comparing the value of dominance (D) to the value of relative frequency $(\mathrm{F})$ and the Shannon-Wiener diversity index:

\section{a. Species Diversity Index}

$$
\mathrm{H}^{\prime}=-\sum \mathrm{Pi} \ln \mathrm{Pi}
$$

H' : Shannon-Wiener Indexs

$\mathrm{Pi}$ : Amount total of individuals

b. Insect Richness Index

$$
\operatorname{Dmg}=\frac{\mathrm{s}-1}{\ln \cdot \mathrm{N}}
$$

Dmg : Margaleaf Wealth index

S : number of species observed

$\mathrm{N} \quad$ : total number of individuals observed

c. Insect Evenness Index

$$
\mathrm{E}=\frac{\mathrm{H}^{\prime}}{\ln \cdot \mathrm{S}}
$$

E : Evenness index

$\mathrm{H}^{\prime}$ : Shannon-Wiener index

$\mathrm{S}$ : number of species observed

\section{RESULTS AND DISCUSSION}

Totally, 1248 individuals of fruit fly were collected and identified. ME and CUE attractants trapped 1076 and 172 individuals, respectively (Table 1). Fruit flies trapped by ME were $B$. dorsalis (Hendel), B. umbrosa (Fabricius), B. carambolae (Drew \& Hancock), and B. occipitalis (Bezzi). The Zeugodacus cucurbitae (Coquillett) was trapped in both types attractants but prefer to CUE rather than ME. The B. albistrigata (de Meijer), Z. caudata (Febricius), B. limbifera (Bezzi), and Dacus nanggalae (Drew \& Hancock) were trapped in CUE attractant only (Table 1).

The preferred of fruit fly species to ME was due to the similarity the content of a compound produced by a plant around the ME trapping location (Sarjan et al., 2010). ME was a compound derived from the extraction of cycads (Cololasia antiquarium), mangoes, papayas, Cassia fistula or Pelae anisata leaves, Ziera sumithui, several essential oils including lemon grass, basil, and also fruits such as oranges, cucumbers, bananas, and some forest fruits (Aluja \& Norrbom, 1999). Plants have volatile compounds that are released as attractant stimuli and can attract insects (Himawan et al., 2013).

The Z. cucurbitae (Coquillett), B. albistrigata (de Meijer), Z. caudata (Fabricius), B. limbifera (Bezzi), D. nanggalae (Drew \& Hancock) were trapped in CUE attractants. According to Hasyim et al. (2014), the CUE attractant traps a different species than the ME attractant. CUE was not a natural product, it was made by rapid hydrolysis in many parts of the plant including species of Rosaceae, Asteraceae, and Lamiaceae. CUE can be found in orchids (Vargas et al., 2010). The Z. cucurbitae (Coquillett) was trapped in both ME and CUE attractants, but prefer to CUE attractant. This result was relevance with Muryati et al. (2008) that $Z$. cucurbitae (Coquillett) was trapped in both types of attractants, but prefer to CUE more. According to Vargas et al. (2010), CUE was more effective attractant to trap Z. cucurbitae (Coquillett). Many of the Tephritidae male species are very interested in certain compounds found naturally in plants (ME) or analogous syntheses of substances stored in plants (CUE).

There were several species from the collected fruit flies that act as pests, such as $B$. dorsalis (Hendel), B. umbrosa (Fabricius), B. carambolae (Drew \&

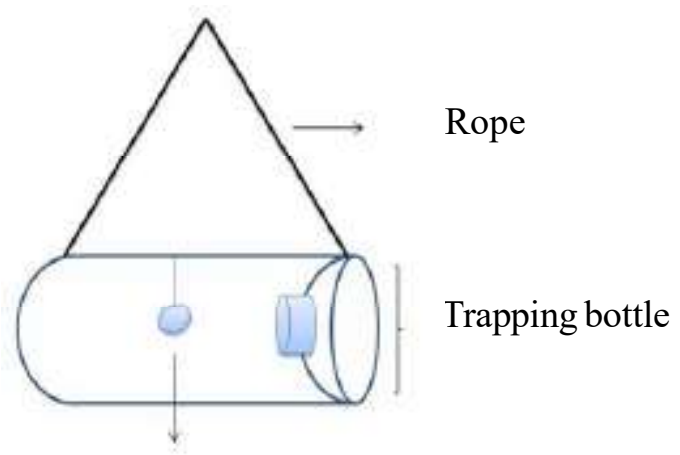

Cotton

Figure 2. Trap of fruit flies. 
Hancock), B. albistriga (de Meijer), B. occipitalis (Bezzi), Z. cucurbitae (Coquillett), and Z. caudata (Fabricius). According to Freidberg et al. (2017), all Dacini subfamilies are fruit eaters or flower eaters and about $10 \%$ of the 932 species recognized today are commercial fruit and vegetable pests. The $B$. limbifera (Bezzi) and D. nanggalae (Drew \& Hancock) fruit flies are not considered plant pests. According to Doorenweerd et al. (2018), not all fruit flies were categorized as pest.

Table 2 showed that each sampling site was collected different types and amounts of fruit flies. The highest number of fruit flies collected in Air Anyir Village were 316 individuals with 9 species found in fruit flies while the lowest number of individuals collected in Jada Bahrin Village were 79 individuals with 8 species of fruit flies found. The large number of fruit fly species in the Air Anyir Village was thought to be a large area of horticultural farms, therefore there were abundant food sources available for fruit flies and there were host plants around the sampling sites. Susanto et al. (2017) stated that, the more availability of host plants in the fields, the greater the population of fruit flies, and fruit flies also use a number of chemical signals to find hosts. The lowest number of fruit fly in Jada Bahrin Village was suspected of chemical control carried out before the day. The difference in the number of fruit fly populations between host was closely related to the presence of fruit, the number of hosts, and adaptation to the environment (Astriyani et al., 2016).

The ambient temperature in the Merawang SubDistrict was around $31.0-35.5^{\circ} \mathrm{C}$ and has a humidity of around $65-86 \%$, this supports the breeding of fruit flies.
According to Armansyah (2014) the optimum humidity for fruit flies to live well is around $62-90 \%$. According to Rahmawati (2014), fruit flies become active in the morning until noon and their activity decreases in the afternoon. According to Manurung et al. (2012), this was closely related to the nature of fruit flies, ectotherms. Ectotherms were animals whose body temperature depends on the temperature of the surrounding environment. In a cool climate, high humidity and winds are not too strong so the attack rate and fruit fly population will increase (Patty, 2012).

B. dorsalis (Hendel), B. carambolae (Drew \& Hancock), B. occipitalis (Bezzi), B. albistrigara (de Meijer) and $B$. limbifera (Bezzi) were species of fruit fly found in all farms of the sampling sites (Table 3).

Fruit fly species trapped in all types of farms were B. dorsalis (Hendel), B. carambolae (Drew \& Hancock), B. occipitalis (Bezzi), B. albistrigara (de Meijer), and B. limbifera (Bezzi). One type of plant can host two or more species of fruit flies (Pramudi et al., 2013). B. dorsalis (Hendel), B. carambolae (Drew \& Hancock), and Z. cucurbitae (Coquillett) are polyphag which attack many hosts of several plant families (Khaeruddin, 2015). The B. umbrosa (Fabricius), B. albistrigata (de Meijer), Z. caudata (Fabricius), B. limbefera (Bezzi), D. nanggalae (Drew \& Hancock) were the few species found in plants in trapping locations. This was related to fruit fly species associated with certain types of host plants, because there were several species of fruit flies that have certain host plants. According to Rahmanda (2017), chili is a true host plant of the species $B$. dorsalis (Hendel) and B. carambolae (Drew \& Hancok). In

Table 1. Species of fruit flies trapped in each attractant on horticultural crops in Merawang Sub-District, Bangka District, Bangka Belitung Islands

\begin{tabular}{|c|c|c|c|c|}
\hline \multirow{2}{*}{ No } & \multirow{2}{*}{ Species } & \multirow{2}{*}{ Total } & \multicolumn{2}{|c|}{ Attractant } \\
\hline & & & $\mathrm{ME}$ & CUE \\
\hline 1 & B. dorsalis (Hendel) & 624 & $\sqrt{ }$ & \\
\hline 2 & B. umbrosa (Fabricius) & 17 & $\sqrt{ }$ & \\
\hline 3 & B. carambolae (Drew \& Hancock) & 267 & $\sqrt{ }$ & \\
\hline 4 & B. occipitalis (Bezzi) & 164 & $\sqrt{ }$ & \\
\hline 5 & Z. cucurbitae (Coquillett) & 84 & $\sqrt{ }$ & $\sqrt{ }$ \\
\hline 6 & B. albistrigata (de Meijer) & 13 & & $\sqrt{ }$ \\
\hline 7 & Z. caudata (Fabricius) & 9 & & $\sqrt{ }$ \\
\hline 8 & B. limbifera (Bezzi) & 69 & & $\sqrt{ }$ \\
\hline 9 & D. nanggalae (Drew \& Hancock) & 1 & & $\sqrt{ }$ \\
\hline & Total Individuals & 1248 & 1076 & 172 \\
\hline
\end{tabular}

$\mathrm{ME}=$ methyl euganol; $\mathrm{CUE}=$ cue lure . 
Table 2. Number and species of fruit flies on horticultural crops in Merawang Sub-District, Bangka District, Bangka Belitung Islands

\begin{tabular}{|c|c|c|c|c|c|}
\hline No & Village & Attractant & Species & Total & Plant \\
\hline \multirow{9}{*}{1} & \multirow{9}{*}{ Balunijuk } & \multirow{5}{*}{ ME } & B. dorsalis (Hendel) ${ }^{1}$ & 93 & \multirow{9}{*}{ Chili } \\
\hline & & & B. umbrosa (Fabricius) ${ }^{1}$ & 6 & \\
\hline & & & B. carambolae (Drew \& Hancock) $)^{3}$ & 44 & \\
\hline & & & B. occipitalis (Bezzi) ${ }^{1}$ & 22 & \\
\hline & & & Z. cucurbitae (Coquillett) ${ }^{3}$ & 1 & \\
\hline & & \multirow{4}{*}{ CUE } & Z. cucurbitae (Coquillett) ${ }^{1}$ & 2 & \\
\hline & & & Z. caudata (Fabricius) $)^{2}$ & 3 & \\
\hline & & & B. limbifera $(\text { Bezzi })^{1}$ & 18 & \\
\hline & & & Total of individuals & 189 & \\
\hline \multirow{9}{*}{2} & \multirow{9}{*}{ Jada Bahrin } & \multirow{4}{*}{ ME } & B. dorsalis (Hendel) ${ }^{1}$ & 12 & \multirow{9}{*}{ Chili } \\
\hline & & & B. umbrosa (Fabricius) ${ }^{1}$ & 1 & \\
\hline & & & B. carambolae (Drew \& Hancock) $)^{3}$ & 8 & \\
\hline & & & B. occipitalis (Bezzi) ${ }^{1}$ & 2 & \\
\hline & & \multirow{5}{*}{ CUE } & Z. cucurbitae (Coquillett) ${ }^{3}$ & 31 & \\
\hline & & & B. albistrigata (de Meijer) ${ }^{1}$ & 1 & \\
\hline & & & Z. caudata (Fabricius) ${ }^{2}$ & 2 & \\
\hline & & & B. limbifera $\left(\right.$ Bezzi) ${ }^{1}$ & 15 & \\
\hline & & & Total of individuals & 72 & \\
\hline \multirow{9}{*}{3} & \multirow{9}{*}{ Pagarawan } & \multirow{5}{*}{$\mathrm{ME}$} & B. dorsalis (Hendel) ${ }^{1}$ & 117 & \multirow{9}{*}{ Orange / Cucumber } \\
\hline & & & 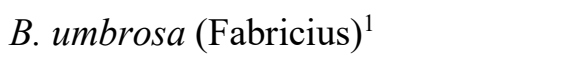 & 1 & \\
\hline & & & B. carambolae (Drew \& Hancock) $)^{3}$ & 48 & \\
\hline & & & B. occipitalis $(\mathrm{Bezzi})^{1}$ & 37 & \\
\hline & & & Z. cucurbitae (Coquillett) ${ }^{3}$ & 3 & \\
\hline & & \multirow{3}{*}{ CUE } & Z. cucurbitae (Coquillett) ${ }^{3}$ & 19 & \\
\hline & & & B. limbifera $(\text { Bezzi })^{1}$ & 12 & \\
\hline & & & B. albistrigata (de Meijer) ${ }^{1}$ & 3 & \\
\hline & & & Total of individuals & 240 & \\
\hline \multirow{10}{*}{4} & \multirow{10}{*}{ Air Anyir } & \multirow{4}{*}{$\mathrm{ME}$} & B. dorsalis (Hendel) ${ }^{1}$ & 128 & \multirow{10}{*}{ Papaya / Chili } \\
\hline & & & B. umbrosa (Fabricius) ${ }^{1}$ & 6 & \\
\hline & & & B. carambolae (Drew \& Hancock) $)^{3}$ & 90 & \\
\hline & & & B. occipitalis (Bezzi) $^{1}$ & 50 & \\
\hline & & \multirow{6}{*}{ CUE } & Z. cucurbitae (Coquillett) & 28 & \\
\hline & & & B. limbifera $(\text { Bezzi })^{1}$ & 10 & \\
\hline & & & Z. caudata (Fabricius) $)^{2}$ & 1 & \\
\hline & & & B. albistrigata (de Meijer) ${ }^{1}$ & 2 & \\
\hline & & & D. nanggalae (Drew \& Hancock) ${ }^{1}$ & 1 & \\
\hline & & & Total of individuals & 316 & \\
\hline
\end{tabular}

$\mathrm{ME}=$ methyl euganol; $\mathrm{CUE}=$ cue lure. 
Table 2. (continued)

\begin{tabular}{|c|c|c|c|c|c|}
\hline No & Village & Attractant & Species & Total & Plant \\
\hline \multirow{8}{*}{5} & \multirow{8}{*}{ Kimak } & \multirow{4}{*}{ ME } & B. dorsalis $(\text { Hendel })^{1}$ & 110 & \multirow{8}{*}{ Papaya/Orange } \\
\hline & & & B. umbrosa (Fabricius) ${ }^{1}$ & 2 & \\
\hline & & & B. carambolae (Drew \& Hancock) & 26 & \\
\hline & & & B. occipitalis $\left(\right.$ Bezzi) ${ }^{1}$ & 37 & \\
\hline & & \multirow{4}{*}{ CUE } & B. limbifera $(\text { Bezzi })^{1}$ & 3 & \\
\hline & & & Z. caudata (Fabricius) $)^{2}$ & 3 & \\
\hline & & & B. albistrigata (de Meijer) ${ }^{1}$ & 1 & \\
\hline & & & Total of individuals & 182 & \\
\hline \multirow{7}{*}{6} & \multirow{7}{*}{ Batu Rusa } & \multirow{4}{*}{ ME } & B. dorsalis $(\text { Hendel })^{1}$ & 164 & \multirow{7}{*}{ Eggplant/Orange } \\
\hline & & & B. umbrosa (Fabricius) ${ }^{1}$ & 1 & \\
\hline & & & B. carambolae (Drew \& Hancock) & 51 & \\
\hline & & & B. occipitalis (Bezzi) $)^{1}$ & 16 & \\
\hline & & \multirow{3}{*}{ CUE } & B. limbifera $(\text { Bezzi })^{1}$ & 11 & \\
\hline & & & B. albistrigata (de Meijer) ${ }^{1}$ & 6 & \\
\hline & & & Total of individuals & 249 & \\
\hline
\end{tabular}

${ }^{1}$ (Khaeruddin, 2015) ${ }^{2}$ (Larasati et al., 2016) ${ }^{3}$ (Plant Health Australia, 2018).

Table 3. Species of fruit flies on horticultural plants in Merawang Sub-District, Bangka District, Bangka Belitung Islands

\begin{tabular}{rlrrrrr}
\hline \multirow{2}{*}{ No } & Species & \multicolumn{5}{c}{ Horticultural plants } \\
\cline { 2 - 6 } & & Chili & Cucumber & Orange & Eggplant & Papaya \\
\hline 1 & B. dorsalis & 160 & 36 & 239 & 90 & 99 \\
2 & B. umbrosa & 12 & 0 & 1 & 1 & 3 \\
3 & B. carambolae & 107 & 6 & 77 & 28 & 50 \\
4 & B. occipitalis & 49 & 10 & 62 & 6 & 37 \\
5 & Z. cucurbitae & 46 & 22 & 0 & 0 & 16 \\
6 & B. albistrigata & 1 & 1 & 4 & 5 & 2 \\
7 & Z. caudata & 5 & 0 & 1 & 0 & 3 \\
8 & B. limbifera & 39 & 4 & 14 & 6 & 6 \\
9 & D. nanggalae & 0 & 0 & 0 & 0 & 1 \\
\hline
\end{tabular}

the research of Larasati et al. (2016), the host of the $B$. carambolae (Drew \& Hancock) was a family of Solanaceae such as eggplant, chillies, tomatoes and rutaceae.

The B. umbrosa (Bezzi) was trapped in chili, eggplant, orange, and papaya. The Z . cucurbitae (Coquillett) was collected in chili, cucumber, and papaya. According to Larasati et al. (2016), B. umbrosa (Bezzi) was associated with the Moraceae (Jackfruit) and $Z$. cucurbitae (Coquillett) associated with Cucurbitaceae. B. albistrigata (de Meijer) were trapped in chili, cucumber, orange, eggplant, and papaya.
According to Khaeruddin (2015), B. albistrigata (de Meijer) was associated with ambarella, turai, guava, water apple, malay apple, carambola, and sapodilla.

Some fruit flies were trapped in the non host plant. It was suspected that there were a host plant around the location of the trap installation site. According to Nurfarida (2017), fruit flies were able to fly 4-15 miles depending on speed, wind direction to find the fruit that is almost ripe. B. occipitalis (Bezzi), Z. caudata (Fabricius), B. limbifera (Bezzi), and D. nanggalae (Drew \& Hancock) do not have a known host plant, therefore information about the presence of plant hosts 
Table 4. Distribution of fruit fly species in the Merawang Sub-District, Bangka District, Bangka Belitung Islands

\begin{tabular}{llllllllll}
\hline & \multicolumn{10}{c}{ Village } & \multicolumn{10}{c}{ Fruit fly species } \\
\cline { 3 - 9 } & 1 & 2 & 3 & 4 & 5 & 6 & 7 & 8 & 9 \\
\hline Balunijuk & $\sqrt{ }$ & $\sqrt{ }$ & $\sqrt{ }$ & $\sqrt{ }$ & $\sqrt{ }$ & - & $\sqrt{ }$ & $\sqrt{ }$ & - \\
Jada Bahrin & $\sqrt{ }$ & $\sqrt{ }$ & $\sqrt{ }$ & $\sqrt{ }$ & $\sqrt{ }$ & $\sqrt{ }$ & $\sqrt{ }$ & $\sqrt{ }$ & - \\
Pagarawan & $\sqrt{ }$ & $\sqrt{ }$ & $\sqrt{ }$ & $\sqrt{ }$ & $\sqrt{ }$ & $\sqrt{ }$ & - & $\sqrt{ }$ & - \\
Batu Rusa & $\sqrt{ }$ & $\sqrt{ }$ & $\sqrt{ }$ & $\sqrt{ }$ & - & $\sqrt{ }$ & - & $\sqrt{ }$ & - \\
Air Anyir & $\sqrt{ }$ & $\sqrt{ }$ & $\sqrt{ }$ & $\sqrt{ }$ & $\sqrt{ }$ & $\sqrt{ }$ & $\sqrt{ }$ & $\sqrt{ }$ & $\sqrt{ }$ \\
Kimak & $\sqrt{ }$ & $\sqrt{ }$ & $\sqrt{ }$ & $\sqrt{ }$ & - & $\sqrt{ }$ & $\sqrt{ }$ & $\sqrt{ }$ & - \\
\hline
\end{tabular}

$\sqrt{ }=$ present, $-=$ absent. $1=B$. dorsalis (Hendel), $2=B$. umbrosa (Fabricius), $3=B$. carambolae (Drew \& rancock), $4=B$. occipitalis (Bezzi), $5=Z$. cucurbitae (Coquillett), $6=B$. albistrigata (de Meijer), $7=Z$. caudata (Fabricius), $8=$ B. limbifera (Bezzi), $9=$ D. nanggalae (Drew \& Hancock).

in fruit fly species is necessary further examined to find out certain host plant.

The results of trapping in the field were not only related to the number of individuals in each species, but also as a description of the distribution of information from fruit flies. Fruit fly species were almost found in all villages and the distribution of the most species of fruit flies was Air Anyir Village, 9 species (Table 4).

Dominance Category. Table 5 showed the species that dominate in the field, viz. $B$. dorsalis (Hendel) and $B$. carambolae (Drew \& Hancock), which trapped in ME attractants that is non-dominant species or rarely found with little abundance.

According to Ginting (2009), the structure of vegetation and the presence of a host can also lead to a limited number of individuals as well as the distribution area. The distribution of fruit flies in Table 4 showed that almost all species of fruit flies were collected. The D. nanggalae (Drew \& Hancock) was only found in Air Anyir Village. This related to the source of foraging and the environment that supports fruit flies to grow and develop. According to Armansyah (2014), there are major barriers that affect the presence of fruit fly species, namely temperature, humidity and habitats that do not support the availability of plants is not a host plant of species that are rarely found.

Fruit Flies Diversity Index. Based on the analysis of species diversity index, Jada Bahrin Village has the highest species diversity index value with a moderate category (1.55), compared to five other villages that were classified as low. The lowest value was observed in Batu Rusa Village (1.03). Species richness was categorized as low in all villages, the highest value was in Jada Bahrin Village (1.64) and the lowest was in Batu
Rusa Village (0.91). Species evenness in the Balunijuk, Jada Bahrin, Pagarawan, and Air Anyir were relatively high, while in Batu Rusa and Kimak Villages were moderate. The highest species evenness value in Jada Bahrin Village was 0.75 and the lowest value was 0.57 in Batu Rusa Village (Table 6). The low value of fruit fly diversity was due to dominancy of one fruit fly species in the field. According to Ginting (2009), a community would have high species diversity index if it was consisted of many species with relatively same abundancy. In the other hand, if the diversity was low, it means that the community was dominated by one species.

Species richness index in all villages was relatively low $(<3)$. High and low species richness was influenced by the large number of collected species. According to Silitonga (2018), species richness describes what species lived in a community. The species evenness index in the Villages of Balunijuk, Jada Bahrin, Pagarawan, Air Anyir is high. This was due to distribution of species observed in the four villages. Batu Rusa and Kimak Villages are categorized as moderate, this was because the number of observed species was relatively uneven. Low species evennes mean uneven distribution of species. The high value of species evennes indicated that the number of individuals of each species was distributed evenly or uniformly (Saragih, 2018). The diversity of fruit flies in Merawang Subdistrict is low. It was indicated by the calculation of diversity index, where the diversity index and species richness of fruit flies were categorized as low and the severity was categorized as high. The alleged low fruit flies in the field due to adaptation to the environment, controlling physical practices carried out by farmers such as the use of insecticides, pesticides, and attractants at the cultivation site. According to Heriza (2017), diversity will be low if the ecosystem or location 
Table 5. Number of individuals and dominant categories of fruit fly species from methyl eugenol and cue lure attractants in Merawang Sub-District, Bangka District, Bangka Belitung Islands

\begin{tabular}{llcccc}
\hline Trap & \multicolumn{1}{c}{ Fruit fly species } & Total individu & Frequency relative (F) & D value & Category \\
\hline \multirow{4}{*}{ ME } & B. dorsalis (Hendel) & 624 & 0.500 & 0.200 & $\mathrm{~d}$ \\
& B. umbrosa (Fabricius) & 17 & 0.014 & 0.200 & $\mathrm{nd}$ \\
& B. carambolae (Drew \& Hancock) & 267 & 0.214 & 0.200 & $\mathrm{~d}$ \\
& B. occipitalis (Bezzi) & 164 & 0.131 & 0.200 & $\mathrm{nd}$ \\
& Z. cucurbitae (Coquillett) & 4 & 0.003 & 0.200 & $\mathrm{nd}$ \\
\hline \multirow{6}{*}{ CUE Cucurbitae (Coquillett) } & 80 & 0.064 & 0.200 & $\mathrm{nd}$ \\
& B. albistrigata (de Meijer) & 13 & 0.010 & 0.200 & $\mathrm{nd}$ \\
& Z. caudata (Fabricius) & 9 & 0.007 & 0.200 & $\mathrm{nd}$ \\
& B. limbifera (Bezzi) & 69 & 0.055 & 0.200 & $\mathrm{nd}$ \\
& D. nanggalae (Drew \& Hancock) & 1 & 0.001 & 0.200 & $\mathrm{nd}$ \\
\hline
\end{tabular}

$\mathrm{d}=$ dominant; $\mathrm{nd}=$ non dominant; $\mathrm{ME}=$ methyl euganol; $\mathrm{CUE}=$ cue lure.

Table 6. Diversity index, wealth, and evenness of fruit fly species in Merawang Sub-District, Bangka District, Bangka Belitung Islands

\begin{tabular}{clccc}
\hline No & Village & Diversity index $\left(\mathrm{H}^{\prime}\right)$ & Wealth index $($ Dmg) & Evenness index $(\mathrm{E})$ \\
\hline 1 & Balunijuk & $1.41 \mathrm{R}$ & $1.14 \mathrm{R}$ & $0.72 \mathrm{~T}$ \\
2 & Jada Bahrin & $1.55+\mathrm{S}$ & $1.64+\mathrm{R}$ & $0.75+\mathrm{T}$ \\
3 & Pagarawan & $1.44 \mathrm{R}$ & $1.28 \mathrm{R}$ & $0.69 \mathrm{~T}$ \\
4 & Air Anyir & $1.48 \mathrm{R}$ & $1.39 \mathrm{R}$ & $0.68 \mathrm{~T}$ \\
5 & Batu Rusa & $1.03-\mathrm{R}$ & $0.91-\mathrm{R}$ & $0.57-\mathrm{S}$ \\
6 & Kimak & $1.12 \mathrm{R}$ & $1.15 \mathrm{R}$ & $0.58 \mathrm{~S}$ \\
\hline
\end{tabular}

$-\mathrm{R}=$ Lowest value, low category; $+\mathrm{R}=$ Highest score, low category; $+\mathrm{S}=$ Highest score, medium category; $+\mathrm{T}$ $=$ Highest score, high category.

was physically controlled by farming activities carried out by farmers.

\section{CONCLUSION}

The diversity of fruit fly species found in Merawang Sub-District, Bangka District, Bangka Belitung Islands was relatively low. There were 9 fruit fly species were observed namely $B$. dorsalis (Hendel), B. umbrosa (Fabricius), B. carambolae (Drew \& Hancock), B. occipitalis (Bezzi), Z. cucurbitae (Coquillett), B. albistrigata (de Meijer), Z. caudata (Fabricius), B. limbifera (Bezzi), and D. nanggalae (Drew \& Hancock). The most dominant fruit flies found at the study site were $B$. dorsalis (Hendel) and $B$. carambolae (Drew \& Hancock). Air Anyir Village weas the villages where the most species of fruit flies were found.

\section{ACKNOWLEDGMENTS}

The author would like to thank the Provincial Government of the Bangka Belitung Islands for providing 2015 PEMPROV Scholarships through undergraduate programs.

\section{REFERENCES}

Aluja M \& Norrbom AL. 1999. Fruit Flies (Tephritidae): Phylogeny and Evolution of Behavior. CRC Press, Washington. 
Armansyah. 2014. Penyebaran lalat buah (Diptera : Tephritidae) di Kabupaten Rokan Hilir. Skripsi. Universitas Islam Negeri Sultan Syarif Kasim Riau, Pekanbaru.

Astriyani NKNK. 2014. Keragaman dan dinamika populasi lalat buah (Diptera: Tephritidae) yang menyerang tanaman buah-buahan di Bali. Thesis. Universitas Udayana. Bali.

Astriyani NKNK, Supartha IW, \& Sudiarta IP. 2016. Kelimpahan populasi dan persentase serangan lalat buah yang menyerang tanaman buah-buahan di Bali. J. Agric. Sci. Biotechnol. 1(5): 19-27.

Badan Pusat Statistika (BPS). 2017. Kecamatan Merawang dalam angka. Badan Pusat Statistika, Kabupaten Bangka.

Doorenweerd C, Leblanc L, Norrbom AL, Jose MS, \& Rubinoff D. 2018. A global checklist of the 932 fruit fly species in the tribe Dacini (Diptera, Tephritidae). ZooKeys 730: 19-56.

Freidberg A, Kovac D, \& Shiao SF. 2017. A revision of Ichneumonopsis Hardy, 1973 (Diptera: Tephritidae: Dacinae: Gastrozonini), oriental bamboo-shoot fruit flies. Eur. J. Taxon. 317: 123.

Ginting R. 2009. Keanekaragaman lalat buah (Diptera: Tephritidae) di Jakarta, Depok, dan Bogor sebagai bahan kajian penyusunan analisis risiko hama. Thesis. Institut Pertanian Bogor, Bogor.

Hasyim A, Setiawati W, \& Liferdi L. 2014. Teknologi pengendalian hama lalat buah pada tanaman cabai. Iptek Hortikultura. 10: 20-25.

Heriza S. 2017. Dinamika populasi lalat buah (Diptera: Tephritidae) pada tanaman buah-buahan di Kabupaten Dharmasraya. Agrin. 21(1): 59-70.

Himawan T, Wijayanto P, \& Karindah S. 2013. Pengaruh beberapa aroma buah terhadap preferensi oviposisi Bactrocera carambolae Drew dan Hancock (Diptera: Tephritidae). Jurnal HPT. 1(2): 72-79.

Isnaini YN. 2013. Identifikasi spesies dan kelimpahan lalat buah Bactrocera spp. di Kabupaten Demak. Skripsi. Universitas Negeri Semarang, Semarang.

Khaeruddin. 2015. Identifikasi lalat buah (Diptera: Tephritidae) di beberapa Kabupaten di Provinsi Sulewesi Barat. Thesis. Institut Pertanian Bogor, Bogor.
Larasati A, Hidayat P, \& Buchori D. 2013. Keanekaragaman dan persebaran lalat buah Tribe Dacini (Diptera: Tephritidae) di Kabupaten Bogor dan sekitarnya. JEI. 10(2): 51-59.

Larasati A, Hidayat P, \& Buchori D. 2016. Kunci identifikasi lalat buah (Diptera: Tephritidae) di Kabupaten Bogor dan sekitarnya. JEI. 13(1): 4961.

Manurung B, Prastowo P, \& Tarigan EE. 2012. Pola aktivitas harian dan dinamika populasi lalat buah Bactrocera dorsalis complex pada pertanaman jeruk di dataran tinggi Kabupaten Karo Provinsi Sumatera Utara. J. HPT Tropika. 12(2): 103110.

Micheal P. 1994. Metode ekologi untuk penyelidikan ladang dan laboratorium. Universitas Indonesia, Jakarta.

Muryati, Hasyim A, \& Riska. 2008. Preferensi spesies lalat buah terhadap atraktan metil eugenol dan cue-lure dan populasinya di Sumatera Barat dan Riau. J. Hort. 18(2): 227-233.

Nawawi R. 2018. Kelimpahan lalat buah (Diptera: Tephritidae) pada berbagai jenis buah-buahan yang terdapat di Pasar Tugu Bandar Lampung. Skripsi. Universitas Islam Negeri Raden Intan, Lampung.

Nurfarida T. 2017. Kelimpahan dan Keanekaragaman Lalat Buah Bactrocera sp. (Diptera: tephritidae) di Pantai Sindangkerta Kecamatan Cipatujah Kabupaten Tasikmalaya. Skripsi. Universitas Pasundan, Bandung.

Patty JA. 2012. Efektivitas metil eugenol terhadap penangkapan lalat buah (Bactrocera dorsalis) pada pertanaman cabai. Agrologia. 1(1): 69-75.

Plant Health Australia. 2018. The Australian Handbook for the Identification of Fruit Flies. Version 3.1. Plant Health Australian, Canberra.

Pramudi MI, Puspitarini RD, \& Rahardjo BT. 2013. Keanekaragaman dan kekerabatan lalat buah (Diptera: Tephritidae) di Kalimantan Selatan berdasarkan karakter morfologi dan molekuler (RAPD-PCR dan Sekunsing DNA). J. HPT. Tropika. 13(2): 191-202. 
Pujiastuti Y. 2009. Penggunaan atraktan dalam monitoring keanekaragaman spesies dan sebaran lalat buah (Diptera: Tephritidae) pada tanaman buah di berbagai ketinggian tempat. Prosiding Semirata PTN Wilayah Barat Bidang Ilmu Pertanian. pp. 1-8. Universitas Sultan Agung Tirtayasa Serang, Banten.

Rahmanda E. 2017. Identifikasi spesies lalat buah genus Bactrocera (Diptera: Tephritidae) pada komoditas cabai (Capsicum sp.) pasar Bandar Lampung. Skripsi. Universitas Islam Negeri Raden Intan. Lampung.

Rahmawati YP. 2014. Ketertarikan lalat buah Bactrocera sp. pada senyawa atraktan yang mengandung campuran protein dan metil eugenol. Skripsi. Universitas Negeri Semarang, Semarang

Saragih MT. 2018. Keanekaragaman jenis semut (Hymenoptera: Formicidae) di kawasan Air Terjun Desa Dalil Kecamatan Bakam Kabupaten Bangka. Skripsi. Universitas Bangka Belitung. Balunijuk.
Sarjan M, Yulistiono H, \& Haryanto H. 2010. Kelimpahan dan komposisi spesies lalat buah pada lahan kering di Kabupaten Lombok Barat. Crop Agro, Scientific Journal of Agronomy 3(2): 103-112.

Silitonga FRH. 2018. Keanekaragaman jenis kumbang (Coleoptera) di kawasan Air Terjun Bukit Maras Desa Dalil Kecamatan Bakam Kabupaten Bangka. Skripsi. Universitas Bangka Belitung. Balunijuk.

Susanto A, Supriyadi Y, Tohidin, Susniati N, \& Hafizh V. 2017. Fluktuasi populasi lalat buah Bactrocera spp. (Diptera: Tephritidae) pada pertanaman cabai merah (Capsicum annuum) di Kabupaten Bandung, Jawa Barat. Jurnal Agrikultura 28(3): 141-150.

Vargas RI, Shelly TE, Leblanc L, \& Piñero JC. 2010. Recent advances in methyl eugenol and cue-lure technologies for fruit fly detection, monitoring and control in Hawaii. Vitam. Horm. 83: 575-595. 